\title{
DINNER AT SENECA'S TABLE: THE PHILOSOPHY OF FOOD
}

\author{
By CHRISTINE RICHARDSON-HAY
}

\begin{abstract}
There is an abundance 'to eat' in the pages of Roman literature, where lavish and exotic dishes crowd the tables at banquets that flatter and fortify indulgent and insatiable appetites in unrestrained festivals of eating and drinking. As Emily Gowers explains, 'Imperium had turned Rome into the world's emporium: its alimentary choices are presented as almost infinite, from the turnips of Romulus to the larks' tongues of Elagabalus'. ${ }^{1}$ Nevertheless, in Roman society, where the food a person ate (its quality, quantity, and presentation) reflected their station in life $^{2}$ and where large numbers of the population struggled at subsistence levels, these literary banquets are neither reliable, nor even factual, accounts of a Roman meal. ${ }^{3}$ In fact, food or events of consumption appear to have occupied an ambivalent, even undistinguished, place in Roman literature, which typically saw their inclusion in comedy, satire, ${ }^{4}$ epigram, and the epistle but not the
\end{abstract}

1 E. Gowers, The Loaded Table. Representations of Food in Roman Literature (Oxford, 1993, repr. 2003), 10. See also J. Griffin, Latin Poets and Roman Life (Bristol, 1985, repr. 1994), 83; C. Edwards, The Politics of Immorality in Ancient Rome (Cambridge, 1993), 173-206.; P. Garnsey, Food and Society in Classical Antiquity (Cambridge, 1999, repr. 2002), 9-10, 145; K. M. D. Dunbabin, The Roman Banquet. Images of Conviviality (Cambridge, 2003), 157; and J. M. Wilkins and S. Hill, Food in the Ancient World (Malden, MA, 2006), 21. Livy (39.6.7-9) marks $187 \mathrm{BC}$ as the date when banquets became more elaborate and cooks, previously slaves, acquired status as artists. Plato also associated cooks with 'imported luxuries into fourth-century Athens' (Wilkins and Hill, xi).

2 'Dining activities communicated aspects of identity and status and contributed towards the establishment of social hierarchies': E. Graham, 'Dining Al Fresco with the Living and the Dead in Roman Italy', in M. Carroll, D. M. Hadley and H. Willmott (eds.), Consuming Passions. Dining from Antiquity to the Eighteenth Century (Stroud, 2005), 51. See Dunbabin (n. 1), 2, $72-102$.

3 Dunbabin (n. 1), 2 notes how little is known about 'the normal family meal in antiquity', warning that literary descriptions 'are often misleading...filled as they are with satirical exaggeration and... archaizing and idealizing references' (3). See also Gowers (n. 1), 3, 7. It is agreed, however, that ancient eating habits were founded on "commensality", that is "sharing a table", with "companions", that is "sharers of bread". Food assembles and binds together those linked by blood (family), class...religion....and citizenship' (Garnsey [n. 1], 6). Dunbabin distinguishes convivium (cf. cena and epulum [78]), 'literally "living together"', as 'the most general Latin term' to describe a large feast or banquet (4). See further, $36 \mathrm{ff}$.

4 There is a particular aptness therefore in the derivation of satire as a culinary metaphor. Gowers (n. 1), 110 enumerates the origins of satura by the grammarian Diomedes (fourth century AD). Two of these are culinary etymologies ('lanx satura, literally, a full dish' and 'a kind of forcemeat or stuffing, a farcimen'), of which 'at least one...is correct'. 
serious genres of epic, tragedy, elegy, or lyric. ${ }^{5}$ Generic considerations could possibly therefore influence an author's inclusion of culinary description in ancient literature, ${ }^{6}$ although food details did not merely satisfy these expectations and were typically shaped by the attitudes, social values, or artistic insights of an individual author. ${ }^{7}$

Gastronomic description also had a place in ancient philosophical writings, where, in a tradition going back at least to Plato, food demonstrated humanity's uncontrolled submission to self-gratification. ${ }^{8}$ Seneca the Younger obviously fits into this tradition, even as the epistle (albeit the moral epistle), a genre receptive to culinary description, was the major form of Seneca's later writings. The austerity of the public banquet given by Q. Aelius Tubero in honour of Scipio Aemilianus (Ep. 95.72-3) is always, for example, a point of virtue in his writings. Using earthenware vessels and goatskins, the banquet was not an extravagant moment of glory but a celebration of virtuous nobility (censura fuit illa, non cena, 'It was a censorship, not a banquet', Ep. 95.72-3). ${ }^{9}$ The episode subsequently cost Tubero success in an upcoming election for praetor (Cicero, Pro Murena, 36.75).

5 Gowers (n. 1), 22-3 writes that 'Common food terms were often enough in themselves to debase a literary text' and make 'a stain on literary decorum'. See also Griffin (n. 1), 67, 82; Wilkins and Hill (n. 1), 250 ff., especially 'Greek and Roman Comedy and Tragedy' (261-8) and 'Roman Satire' (268-9). The satires of Horace (2.2, 2.4, 2.8), Juvenal (5, 11), Persius (1), and Petronius' Satyricon (47 ff.) all offer memorable examples of Roman eating.

6 The language of satire and comedy was also prominently served by gastronomic detail and imagery, e.g. farrago (Juvenal, 1.86); plebeia prandia (Persius, 5.18); aliquid decoctius (Persius, 1.25). A vocabulary of literary style also developed so that a text could have 'taste' (sapere, gustare) or require 'seasoning' (condimentum), its style being either 'fat' (pinguis, turgidus, opimus, adipatus) or 'thin' (gracilis). J. C. Bramble has examined this detail extensively in the work of Persius, Persius and the Programmatic Satire. A Study in Form and Imagery (Cambridge, 1974), esp. 45-59. Note also Gowers (n. 1), 40 ff., 109-26. See also Quintilian, 2.10.6; 5.14.35; $6.3 .19 ; 6.3 .96 ; 9.3 .27 ; 12.2 .4 ; 12.10 .38$.

7 'The meal is often described loosely as a microcosm of the society in which it takes place' (Gowers [n. 1], 25). See Garnsey (n. 1), 10; Wilkins and Hill (n. 1), 245; and Dunbabin (n. 1), 3-4, who comments that even those authors 'that give the greatest appearance of objectivity, write with their own biases'. She also stresses how visual representation of the banquet, 'like much of Roman art, was fundamentally multivalent and owed much...to its ability to convey a range of significance' (7).

8 See Griffin (n. 1), 37, n. 24.

9 The Latin text of Seneca's Epistulae Morales (2 vols., 1965) and Dialogi (1977) are from the Oxford Classical Texts series, edited by L. D. Reynolds. Translations of the Epistulae Morales are taken from R. M. Gummere's three-volume edition in the Loeb Classical Library (vol. 1, 1917, repr. 1989; vol. 2, 1920, repr. 1991; vol. 3, 1925, repr. 1989). Translations of the Dialogi are from the three-volume edition of Seneca's Moral Essays by J. W. Basore in The Loeb Classical Library (vol. 1, 1928, repr. 1970; vol. 2, 1932, repr. 1996; vol. 3, 1935, repr. 1989). Acknowledgement is made here to both Gummere and Basore for the translations that occur from these works in the following discussion, in which the Epistulae Morales and the Dialogi serve as the main focus. Senecan drama is not discussed. Text and translations of the Naturales Quaestiones are taken from T. H. Corcoran's two-volume edition in The Loeb Classical Library (vol. 1, 1971, repr. 1999; vol. 2, 1972). 
This acknowledgment of Seneca's attention to food detail is conventional, yet inadequate. Culinary experiences, the language and imagery of food, ${ }^{10}$ fat and fastidious diners occur frequently in Seneca's writings and stand out decisively and memorably. ${ }^{11}$ In Epp. 2 and 84 of the Epistulae Morales, for instance, Seneca uses the metaphor, popular among writers of all genres, of reading as eating, in which reading was equated with digestion and was intellectual 'nourishment' for the reader. ${ }^{12}$ Authors liked to depict themselves as 'cooks' or 'hosts' offering a 'banquet of learning' (discendi epulas, Cicero, Topica, 25), but in these letters Seneca deftly appropriates this concept to present his teaching about the best method of philosophical reading.

Careful and discerning 'digestion' of an author's works will not just reinforce and extend knowledge but will in turn be a means that will enable the reader to produce something new himself. This is the basis of all 'therapeutic' reading in both letters (alit lectio ingenium... concoquamus illa, 'Reading nourishes the mind...We must digest it', Ep. 84.1, 7). ${ }^{13}$ Thus, in Ep. 2, Seneca quickly rebukes Lucilius for an 'overnice appetite' (in books and authors) that merely 'toys with many dishes' (fastidientis stomachi est multa degustare, Ep. 2.4). Just like the countless dishes of food tasted and discarded by fastidious diners in

10 Like satirical writers, Seneca uses phrases in stylistic discussions such as inopia et exilitas, 'poverty-stricken and thin-spun style', Ep. 40.3 or ieiuna...et arida, 'meagre and dry' writings, Ep. 75.3, which evoke physical images and have associations with eating and drinking. Maecenas' eloquence resembles that of a drunken man, 'twisting, turning, unlimited in its slackness' (eloquentiam ebrii hominis involutam et errantem et licentiae plenam, Ep. 114.4; cf. orationis...ebrietas, Ep. 114.22). And, while luxurious banquets and elaborate dress are signs of a diseased state, their presence mirrors the lax style of an unstable animus (Ep. 114.11).

11 Gowers (n. 1) cites Seneca consistently in her introductory chapter, giving him context in the larger tradition of Roman food writing. She, however, attributes the speech of De Tranq. An. 1.9 (14 and n. 52) directly to Seneca (who 'pictures himself as an island of integrity in the swelling flood of luxury'). Although the sentiments belong to Seneca, the speaker is actually Serenus, to whom the work is dedicated.

12 See Cicero, De Divinatione, 1.29.61; Brutus, 126; De Officiis, 1.105; Quintilian, 1.8.6, 8; 2.4.5; 8.pr.2; 11.2.41; 12.6.6; Horace, Epistles, 2.2.61-4; Pliny, Letters, 3.5; Plutarch, Table Talk, 6.pref.686a-e. Macrobius dedicated his Saturnalia to his son in the hope of providing him with 'nourishment' for the rest of his life (Pref. 1-6). The Bible later became a major source of this concept: see E. R. Curtius, trans. W. R. Trask, European Literature and the Latin Middle Ages (London, 1979) 134-5: 'Those who hunger and thirst are called blessed...For Augustine God is "interior cibus" (Conf. I, 13, 21, 5), truth is nourishment (Civ. Dei, XX, 30, 21) and food (Conf. IX, 10, 24, 12)'. See Bramble (n. 6), 51-2 and Gowers, (n. 1), 40 ff.

13 certis ingeniis inmorari et innutriri oportet, 'You must linger among a limited number of master-thinkers and digest their works', Ep. 2.2; unum excerpe quod ille die concoquas, 'select one [thought] to be thoroughly digested that day', Ep. 2.4. See M. Graver, Therapeutic Reading and Seneca's Moral Epistles, unpublished PhD thesis, Brown University, 1996. Also Epp. 6.5; 39.1-2; 108.35; De Tranq. An. 9.5. 
satirical writings, ${ }^{14}$ his reading 'cloys' but does not 'nourish' (inquinant non alunt). ${ }^{15}$ The effectiveness of Seneca's use of this food metaphor is enhanced in Ep. 2 by its integration and contextualization with Ep. 2's theme of the aeger animus (demonstrated by discursiveness and a person's failure to cope with paupertas).

Looking beyond metaphor and imagery, A. L. Motto regards Seneca's use of culinary detail and his exposition of Roman eating as an overlooked tribute to his skills as a satirist. ${ }^{16}$ She describes him as 'debunking the dining habits of the Neronian Age'17 in his own attempt to safeguard public standards and reform social behaviour. Undoubtedly, as Motto asserts, such episodes demonstrate Seneca's 'multifaceted talent', ${ }^{18}$ but the ethical significance of Seneca's gastronomic moments goes beyond a generalized 'debunking' of the greed of his fellow Romans. If Seneca, as a moralist, can sometimes be called a 'satirist', it is because he is always at heart the concerned and involved philosopher, whose main purpose (despite any of his own issues) is to teach and motivate others. Seneca uses genre and manipulates stylistic or rhetorical devices, but he does not simply use them for their sake alone, as an exercise of literary skill. ${ }^{19}$

Rather than clever, satirical moments that can stand alone, a sense develops in Seneca's writings of food as a separate 'language' with its own resonance, insight, judgment, and resolution. Seneca's culinary

15 Gowers (n. 1), 19 emphasizes the prominence of 'fussiness' in food representations in comedy and satire ('another kind of aberration from primeval simplicity'). Such fastidiousness could have been fuelled by ancient cook books that were 'designed for reading', their purpose 'to inspire and amuse the diner rather than the cook' (Wilkins and Hill [n. 1], 245-6). For similar references in Seneca's writings, see Epp. 58; 66.25; 95.27; 118.5; 119.15-16; 122.14,18; 123.2; Ad Helv. 10.3; Nat. Quaest. 4B.13.6. See further T. D. Hill's discussion on fastidium and death/suicide in Seneca's works in Ambitiosa Mors. Suicide and Self in Roman Thought and Literature (London and New York, 2004), 159, 175-8.

15 In Ep. 84.3 ff., Seneca advises humankind to follow the example of bees, which cull honey-rich flowers and store in cells all that they have gathered. In the preface to the Saturnalia, Macrobius equates the knowledge that he has stored there for his son's nourishment with the bees' gathering of pollen from a hundred flowers into a unique and special honey. Bramble (n. 6), 52 notes the 'common identification' in ancient literature 'between poetry, and nectar or honey', e.g. Lucretius, De Rerum Natura, 1.947; Horace, Epistles, 1.19.44.

16 A. L. Motto, 'Seneca's Culinary Satire', in Further Essays on Seneca (Frankfurt-am-Main, 2001), 169-83.

17 Ibid., 170.

18 Ibid., 179. Both literary and philosophical, Seneca's works span a number of genres, including scientific works (Naturales Quaestiones), and tackle sometimes unexpected subjects, not only outside Stoicism but even outside the philosophical realm (Quintilian, 10.1.129). This versatility is the emphasis of a recent study by K. Volk and G. D. Williams (eds.), Seeing Seneca Whole. Perspectives on Philosophy, Poetry and Politics (Leiden and Boston, 2006).

19 Brad Inwood, Reading Seneca. Stoic Philosophy at Rome (Oxford, 2005), 5 (see also 31), confirms how 'the philosophy in Seneca's work is a central preoccupation rather than an elaborate excuse for stylistic and rhetorical fireworks...a full understanding of Seneca's literary achievement cannot come without the deep and uncompromising engagement in philosophy'. 
description is, in effect, a specialized commentary that works with its own effectiveness to question moral attitude, develop ethical knowledge, and resolve philosophical experience. With food as a recurrent and popular subject in contemporary satire and comedy, typical literary descriptions of eating habits provide a vivid jumping-off point for Seneca's own exposition. Playing on this double focus, he can draw out the philosophic inference and association of these details to emphasize, qualify, and vitalize (by means of surprise, paradox, and antithesis, for example) particular concepts and arguments, their practical consequences and rational effects. An intense and demanding author, both in subject matter and in the response that he requires from readers, Seneca's moral purpose constantly influences interpretation of his details, and their effect can never be taken for granted. Significantly, Seneca's descriptions of food are often distinguished by their graphic nature, a deliberate aspect of his style (especially his tragedies) ${ }^{20}$ that can be demonstrated simply by the length ${ }^{21}$ or specificity of his descriptions, ${ }^{22}$ or his keen use of real-life exempla. ${ }^{23}$

Just as Seneca uses the language of the law, money, and accounting, and imagery of landscape, place, or the suffering body in his writings to stimulate, vivify, enforce, and strengthen his argument, ${ }^{24}$ culinary description is another 'dialect' in his language of moral exposition and a penetrating means of exemplifying and exposing human irrationality, moral weakness, and philosophical shortcomings. The public ethos and social interest of satire is subsumed in the objectives and decisions of a discussion that is doctrinal, pedagogical, and therapeutic. This is the voice of individual philosophical knowledge and

20 C. Edwards, 'The Suffering Body: Philosophy and Pain in Seneca's Letters', in J. I. Porter (ed.), Constructions of the Classical Body (Ann Arbor, MI, 1999, repr., 2002), 255, refers to 'Seneca's obsessively vivid and detailed explorations of the material world'. Making a link with satire, R. Tarrant, 'Seeing Seneca Whole?', in Volk and Williams (n. 18), 7, writes that 'Seneca's evocations of vice have a vividness and an eye for telling detail worthy of Juvenal'. For the tragedies, see J. Shelton, 'The Spectacle of Death in Seneca's Troades' and E. R. Varner, 'Grotesque Vision: Seneca's Tragedies and Neronian Art', both in G. W. M. Harrison (ed.), Seneca in Performance (London, 2000), 87-118, 119-36.

${ }^{21}$ For example, Epp. 78.25-7; 95.18 ff.; 110; 119.4-15; 122; Ad Helv. $10.1 \mathrm{ff}$.

${ }^{22}$ For example, Epp. 47.2-8; 95.26; 114.26-7; De Vita Beata, 11.4; De Brev.Vit. 12.5; Ad Helv. 10.3, 8 .

${ }^{23}$ For example, Ad Helv. 10.4, 8; De Vita Beata, $11.2 \mathrm{ff}$.

24 C. S. Smith, Metaphor and Comparison in the Epistulae ad Lucilium of L. Annaeus Seneca (Baltimore, 1910); Sister B. M. Allen, 'The Vocabulary of Accounting in Seneca', Cf 61 (1966), 347-9; G. B. Lavery, 'Metaphors of War and Travel in Seneca's Prose Works', GER 27 (1980), 147-57; C. Segal, 'Boundary Violation and the Landscape of the Self in Senecan Tragedy', Antike und Abendland 29 (1983), 172-87; C. Edwards (n. 20), 252-68; J. Henderson, Morals and Villas in Seneca's Letters. Places to Dwell (Cambridge, 2004); and M. von Albrecht, Wort und Wandlung. Senecas Lebenkunst, Mnemosyne supplementa 252 (Leiden, 2004). 
moral transformation, and satire in this context becomes philosophy's tool. In the tradition of the Greek symposium, ${ }^{25}$ philosophy transcends a base concern with eating and drinking, despite Seneca keeping his focus deliberately on the food and the diners before him. Like other Roman writers of the time, Seneca's purpose with regard to food is his own.

\section{The 'ingredients' of food's philosophy}

It is not the comestibles but the central issues of Stoic philosophy that are the 'food' on the plate at Seneca's banquets and it is inevitable that the corporeal nature of food, its bodily manifestation and physical necessity, makes it a potent and natural inroad into Stoic conceptions of the animus. In Stoic thinking the animus was the centre of man's moral being (ipsum principale, ep. 92.1; rex noster est animus, Ep. 114.23) and, in Seneca's writings, it very often comes to represent his conception of a person and their character (Epp. 10.3; 11.10; 13.1; $34.3-4 ; 114.22)$. The animus was the rational force that governed modes of perception and impelled patterns of behaviour (motivation, purpose, judgment, choice: Epp. 45.9; 71.27; 92.11) and enforced moral nature to determine a person's intellectual and spiritual existence (Epp. 66.6; 98.2; 114.22-5). Distinct from the animus and secondary to it (Epp. 78.10; 92.1), the corpus was regarded as an encumbrance that could impede the pursuit of wisdom and ethical probity (Epp. 65.16; 92.33, cf. Plato, Phaedo, 65a-b). Quoting Posidonius, Seneca marks out this differentiation directly in terms of eating: prima pars hominis est ipsa virtus; huic committitur inutilis caro et fluida, receptandis tantum cibis habilis ('Man's primary art is virtue itself; there is joined to this the useless and fleeting flesh, fitted only for the reception of food', Ep. 92.10). Paradoxically, the animus was often classified in bodily terms of 'health' or 'disease' (Epp. 2.1; $15.1-2 ; 34.4),{ }^{26}$ which, in the world of food, had real, corporeal

${ }_{25}$ Motto (n. 16), 169 notes the difference between the Roman cena and the Greek symposium 'where learned guests convened and converted the dining experience into a philosophic feast of reason'. Gowers (n. 1), 29 asserts how, in comparison to the symposium, 'the Roman cena was inescapably weighed down by food'. See also C. Edwards, Death in Ancient Rome (New Haven and London, 2007), 178.

${ }^{26}$ The 'Stoics...say that virtue is the health of the soul, and that it is equivalent to tranquillity, the natural condition of the soul' (T. Brennan, The Stoic Life. Emotions, Duties and Fate [Oxford, 2005], 127). In keeping with ancient conceptions of the philosopher, one of Seneca's favourite self-representations is as the 'doctor' of the soul. His doctrines are 'prescriptions' to help 'recover' the 'sick' soul (ep. 8.1-2). 
manifestations - a distended paunch, ${ }^{27}$ nausea, vomit, indigestion, physical debilitation, an insatiable thirst (Ep. 95.25; 114.25; Ad Helv. 10.3). Stressing the simplicity of an earlier age in contrast to the complexity of the foods in which people now indulge (illa purulenta, Ep. 95.25), Seneca keenly lists the multiplicity of resulting diseases in Ep. 95.16-18, from dropsy to a fevered brain and internal ulcers. Ironically, the pleasures of eating end up being tortures, not only physically (epulae cruditatem adferunt, ebrietates nervorum torporem tremoremque, 'banquets bring indigestion, carousals paralysis of the muscles and palsy', Ep. 24.16) but also spiritually, in their effect on the animus. Greedy men who stuff their distended bodies with still more food will find that their souls swell simultaneously with every extra mouthful of food (ne cibis quidem inplendi sunt; distendentur enim corpora et animi cum corpore tumescent, De Ira 2.20.2).

The 'diseases' that Seneca describes result from the bodily act of eating, yet these are the symptoms (for example, greed, desire, self-indulgence) not of a sick body but a 'sick' soul (magisque animo quam corpore morbidis, Ep. 78.25). The real substance of a meal is not the food that someone puts in his mouth but the conception he has of its necessity, quantity, or quality. Motivated by an 'insanity of greed and luxury' (insaniam... auaritiae atque luxuriae, Ad Helv. 10.1) - that is, states of emotion, moral indecision, and irrationality - some folk simply open their mouths and gulp down all they can into their protruding bellies, even though not even this extension can hold all they try to force down (nonne furor et ultimus mentium error est, cum tam exiguum capias, cupere multum?, 'Is it not madness and the wildest lunacy to desire so much when you can hold so little?', Ad Helv. 10.6). The images of fat people, over-indulged, ill, and enervated (Epp. 95.18; 114.25) by the grossness of their appetites (Ad Helv. 10.2-7), are the bodily forms of animi that have sat down to dinners of self-delusion and moral misapprehension (quantum fastidium sui exhalantibus crapulam veterem!, 'how disgusted men are with themselves when they breathe forth the fumes of yesterday's debauch!', $E$ p. 95.25). They are people who do not know the measure of a mouthful (quantum capiam adhuc nescio, Ep. 59.13), but nor do they want to know because, when the body is in control, nothing satisfies greed (cupiditati nihil satis est, Ad Helv. 10.11). The insatiable soul will

27 Plato brings out the philosophical opposition between the soul and the stomach in Timaeus, 70-1: 'The appetite for food and drink...they located between the midriff and the region of the navel...that it...be as far as possible from the seat of deliberation' (quoted in Wilkins and Hill [n. 1], 188-9). 
never be satisfied because insatiability is not need and only signifies disease (numquam explebunt inexplebilem animum...enim...illa...morbus est, Ad Helv. 11.3). ${ }^{28}$

The concept of the animus, which defines Stoic ideas of sapientia, ratio, and virtus, is presented corporeally as physical attitude and material need, a paradox that is inherent in Stoic notions of the soul. ${ }^{29}$ People with an outsized belly or a perpetually open mouth have skinny, underfed spirits (corpora in sagina, animi in macie et veterno sunt, Ep. 88.19). But, unlike people who suffer from a physical illness and are unable to control their pain, the over-eater can remedy his own condition (si ad sanam illis mentem placeat reuerti, quid opus est tot artibus uentri servientibus?, 'if men should be willing to return to sanity of mind, what is the need of so many arts that minister to the belly?', Ad Helv. 10.5) ${ }^{30}$ Or can he? Time and again, Seneca draws attention to the moral weakness that traps a man in his greed and the desire to have more (non fames nobis ventris nostri magno constat sed ambitio, 'It is not the natural hunger of our bellies that costs us dear, but our solicitous cravings', Ep. 60.3). ${ }^{31}$ In fact, rather than satisfying his hunger, he will stubbornly seek to arouse his appetite and whet his gluttony (quaerit quemadmodum post saturitatem quoque esuriat, quemadmodum non impleat ventrem sed farciat, 'a luxury which seeks how it may prolong hunger even after repletion, how to stuff the stomach, not to fill it', Ep. 119.14). What would have been nourishment to a hungry man instead becomes a burden to an already full stomach (quae desiderantibus alimenta erant onera sunt plenis, Ep. 95.15).

Having fallen 'to the level of the eating house and the belly' where an individual's only concern is what to drink and eat, ${ }^{32}$ people do not

28 Cf. Horace, Satires, 2.8 .

29 The Stoics were 'physicalists' and had a corporeal notion of the soul (Ep. 106.4 ff.). J. E. Annas, Hellenistic Philosophy of Mind (Berkeley, Los Angeles, and London, 1992), 37, writes: 'They claim that soul is body, a physical thing, and by physical thing, they uncompromisingly mean a three-dimensional solid object'. See A. A. Long and D. N. Sedley (eds.), The Hellenistic Philosophers, vol. 1 (Cambridge, 1987, repr. 2001), 71-2; T. H. Irwin (ed.), Classical Philosophy (Oxford, 1999), 222 ff.; B. Inwood (n. 19), 249-51, 322-52; T. Brennan (n. 26), 124-9.

30 See Ep. 78.23-5; De Vita Beata, 11.4; Nat. Quaest. 4B.13.5; cf. the 'crooked soul' (Epp. $11.10 ; 34.4 ; 88.13)$.

31 This is action that defies the nature of virtue: eadem natura est in omni desiderio quod modo non ex inopia sed ex uitio nascitur: quidquid illi congesseris, non finis erit cupiditatis sed gradus ('Every want that springs, not from any need, but from vice is of a like character; however much you gather for it will serve, not to end, but to advance desire', Ad Helv. 11.4). See also Ep. 89.22; Ad Helv. 11.6. Comparing diseases of the body and the soul, Seneca notes how eventual acknowledgment of bodily illness does not occur with diseases of the soul, where 'the worse the one is, the less one perceives it' (quo quis peius se habet, minus sentit, Ep. 53.7).

32 The reference is to Ad Marc. 22.2: in popinam uentremque procubuerunt toti summaque illis curarum fuit quid essent, quid biberent. 
even have the intuition to know that the best cook, paradoxically, is hunger itself (nihil contemnit esuriens...contenta desinere est; quo desinat non nimis curat, 'A starving man despises nothing... [hunger] does not care very much what food brings it to an end', Ep. 119.4, 14). ${ }^{33}$ The most desirable food can be the least 'nourishing' (quaedam quae laudantur atque adpetuntur contra eos esse quos delectauerunt, simillima cruditatibus ebrietatibusque et ceteris quae necant per uoluptatem, 'Things which are lauded and sought after are sometimes to the hurt of those who delight in them, being very much like over-eating, drunkenness, and the other indulgences which kill by giving pleasure', De Prov. 3.2) ${ }^{34}$ It weighs on the animus (animum corpori addixit, Ep. 90.19) and leaves it debilitated by its own physicality (nunc quod maiore corporis sarcina animus eliditur et minus agilis est, 'By overloading the body with food you strangle the soul and render it less active', Ep. 15.2). Hence, as diners revel at lavish banquets, eat the last morsel, and drink the last drop, they are metaphorically dining on poison (uenena edebat bibebatque, Ad Helv. 10.10). Lauding the poverty of Fabricius, who eats only home-grown roots and herbs, Seneca asks cynically, felicior esset, si in uentrem suum longinqui litoris pisces et peregrina aucupia congereret? ('Would he be happier if he loaded his belly with fish from a distant shore and with birds from foreign parts?', De Prov. 3.6) ${ }^{35}$

In an ideal situation, it should be possible for anyone to reject even what is necessary (Ep. 110.12) but, driven by extremes, a person becomes their appetite (cf. cibus adiutorium corporis nec tamen pars est, 'Food is an aid to the body, but is not a part of it', Ep. 88.25). In fact, though, it is the animus and not food that can make us replete (corpus enim multis eget rebus ut valeat: animus ex se crescit, se ipse alit, se exercet, 'For although the body needs many things in order to be strong, yet the mind grows from within, giving to itself nourishment and

33 See Epp. 78.22; 95.18; 123.2; cf. Cicero, Tusculan Disputations, 5.34.97-100.

${ }^{34}$ Cf. Ep. 83.27: quae voluptates vocantur, ubi transcenderunt modum, poenas esse ("What men call pleasures are punishments as soon as they have exceeded due bounds'). Nomentatus and Apicius, an epicure famous in Tiberius' time (scientiam popinae professus, 'professor of the science of the cookshop', Ad Helv. 10.8), are prominent exempla of Seneca's argument: aspice Nomentanum et Apicium, terrarum ac maris, ut isti uocant, bona conquirentis...nec tamen illis bene erit, quia non bono gaudent ('Look at Nomentatus and Apicius, digesting, as they say, the blessings of land and sea...and yet it will not be well with them, because what they delight in is not a good', De Vita Beata, 11.4). Apicius' cookery book, which is one of few that have survived since ancient times, in a compilation from the fourth or fifth century, is notable for an extensive use of costly and imported ingredients. See Garnsey (n. 1), 37, 121-2; Wilkins and Hill (n. 1), 150-2, 207-8. Pliny, Natural History, 10.133 notes flamingo tongues as an introduction of Apicius.

${ }^{35}$ Cf. Cicero's reference to the plain fare of Laelius the Wise (De Finibus, 2.8.24). Laelius was called 'the Wise' because of the small value he placed on good eating. Laelius is acknowledged by Seneca on several occasions as a figure of moral probity (e.g. Epp. 7.6; 11.10; 95.72). 
exercise', Ep. 80.3$)^{36}$ because, unlike the stomach, it cannot be limited by satiety (satietas sui) ${ }^{37}$ or misled by the deception of pleasure (falsa satiabunt, Ep. 78.26). The animus, which functions by means of reason and knowledge or judgment and good decision, can satisfy a person and fill them up so that they do not want any more (plus reddet quam acceperit, '[the mind] gives back more than it receives', Ep. 38.2). Seneca's point is also, however, that a human being does not require much. People with eager, open mouths need only to learn how to shut their mouths to 'open' their souls. Or, as Seneca asserts succinctly, 'Food has nothing to do with virtue' (cibus tamen ad virtutem non pertinet, Ep. 88.31). ${ }^{38}$

Stoicism, especially as Seneca presents it in the Epistulae Morales, was not a philosophy for the infallible wise man who had already reached or was likely soon to achieve perfect wisdom. Even at the end of his own life, Seneca still regarded himself as a proficiens and was never afraid to state his own inadequacies (Epp. 6.1; 7.1-2; 8.2; 57.3; $71.30 ; 87.4-5)$. Hence, the emphasis of Seneca's teaching, and Stoicism in general, was on individual integrity and the motivation and effort of each person to accomplish their goals and live the good life as a happy, free, and knowing individual. ${ }^{39}$ Stoic actions were

36 See also Ad Helv. 11.5: in solitudinibus asperrimis, cum quantum satis est sustinendo corpori inuenit, ipse bonis suis abundat et fruitur ('in the wildest wilderness, having found there all that the body needs for its sustenance, [the soul]... overflows in the enjoyment of its own goods').

37 The 'distinctive quality' of the happy life is 'its fullness'. 'Satiety', however, is 'the limit to our eating and drinking' (quid autem est in beata vita eximium? quod plena est. finis...edendi bibendique satietas est, Ep. 85.23). Epicurus writes that 'The stomach is not insatiable, as the many say, but rather the opinion that the stomach requires an unlimited amount of filling is false.' See B. Inwood and L. P. Gerson (eds.), The Epicurus Reader. Selected Writings and Testimonia (Indianapolis and Cambridge, 1994), 39, no. 59.

38 Cicero states that people whose stomachs are full of food and drink cannot make proper use of their minds (quod ne mente quidem recte uti possumus multo cibo et potione completi, Tusculan Disputations, 5.35.100; text and translation from the Loeb edition by J. E. King [1927, repr. 1996]).

39 A person's life consisted of morally significant situations, emotions, and ideas (good, bad, easy, difficult) that had to be confronted daily and determined in terms of either pursuit or avoidance (EPp. 66.6; 82.6; 84.11). These actions were deliberate, self-conscious decisions, internally mediated and arbitrated by Reason (Epp. 31.9-11;66.31-4;92.1;95.57;99.18; De Ben. 4.10.2) and it was the responsibility of each individual to make their own choices and understand their moral commitment. Ideally, an action could be regarded as an act of virtue $(E p$. 66.6), as something just and right and in accordance with Nature's will (Ep. 71.2). It is only when one recognizes what one owes oneself in terms of nature $(E p p .59 .13 ; 121.3)$ that one can understand what to seek and what to avoid (Epp. 44.7; 104.16) - quidni petam? non quia bona sunt, sed quia secundum naturam sunt, et quia bono a me iudicio sumentur ('Of course I shall seek them, but not because they are goods, I shall seek them because they are according to nature and because they will be acquired through the exercise of good judgment on my part', Ep. 92.11). See Inwood's chapters 'Moral Judgment in Seneca' and 'Reason, Rationalization, and Happiness' (n. 19), 201-23, 249-70.The Stoics stressed the need for a goal (telos), e.g. summum bonum, by which one could organize one's life and make right decisions (Epp. 71.1-3; 95.43-6). 
moments of self-responsibility (sibi fidere, Ep. 31.3) and self-actualization (ut te meliorem cotidie facias, 'you make it each day your endeavour to become a better man', Ep. 5.1), and constituted a process of inner transformation that involved self-knowledge (Ep. 29.11) and an individual's moral discoveries (nullum [bonum] autem est nisi quod animus ex se sibi invenit, 'But there can be no such good except as the soul discovers it for itself within itself', Ep. 27.3). ${ }^{40}$ Hence Seneca opens the Epistulae Morales with an exhortation that could hardly be briefer but which commands an act of profound inner purpose and moral definition - vindica te tibi (Ep.1.1) - a liberation not only by the Self but for the Self. It is possible for anyone to change, mould, and develop their Self.

Of course, everyone must eat to survive, but every human being controls what they eat and Seneca uses this idea repeatedly as a metaphor of individual moral intention (cibus famem domet...discamus continentiam augere, 'Let food subdue hunger...let us learn to increase our self-control', De Tranq. An. 9.2). Unfortunately, some people do not even have the self-command to know whether they really are hungry and want to eat (usque eo nimio delicati animi languore soluuntur ut per se scire non possint an esuriant, 'So enfeebled are they by the excessive lassitude of a pampered mind that they cannot find out by themselves whether they are hungry', De Brev.Vit. 12.6) Thus they wallow at banquets, depending in banal and pathetic ways on others, such as a hovering slave ${ }^{41}$ or the hunter and farmer whose function it is to supply the food that is so much their pleasure (quantum hominum unus venter exercet!, 'How many men are kept busy to humour a single belly!', Ep. 95.25). Basic, readily available provisions are disregarded in favour of special items such as thousand-pound boars or flamingo tongues (milliarios apros nec linguas phoenicopterorum, Ep. 110.12), for which men scour the world in any effort to bring them to table. ${ }^{42}$ The earth's resources are hostage to the satisfaction of people's stomachs (profunda et insatiabilis gula, Ep. 89.22; fastidienti gulae...dissolutus deliciis stomachus, Ad Helv. 10.3), the vastness of the search imaged in

40 G. Reydams-Schils, The Roman Stoics. Self, Responsibility, and Affection (Chicago and London, 2005), 51, defines the Stoic self as 'a unitary, existentially informed, mediating psychological notion'.

41 adice obsonatores quibus dominici palati notitia subtilis est...quod illo die esuriat, 'Think also of the poor purveyors of food, who note their masters' tastes with delicate skill....and what will stir them to hunger on that particular day', Ep. 47.8. Cf. De Brev. Vit. 12.5.

42 fomenta corporum et cibi...nos magnis multisque conquirenda artibus fecimus ('Creature comforts, food...we that have caused them to be sought for by extensive and manifold devices', Ep. 90.18). Seneca is always vivid on this point (see Epp. 60.2; 89.22; 114.26; Ad Helv. 10.2-3). 
the bloated capacity of these constantly full bellies. The extravagant pointlessness of such hunts exposes an arbitrary self-responsibility, which, determined by self-delusion, extends only as far as the next meal and contradicts the practical virtue and self-sufficiency of rational ethics (Ep. 124.20): immunes erant ab istis malis qui nondum se delicis solverant, qui sibi imperabant, sibi ministrabant ( 'Men used to be free from such ills, because they had not yet slackened their strength by indulgence, because they had control over themselves, and supplied their own needs', Ep. 95.18). ${ }^{43}$ Like the fool who can not be trusted with himself (Ep. 59.17) and characteristically betrays himself (Ep. 10.1-2), this kind of behaviour matches the eating habits of a hungry dog. Lacking restraint, the dog snaps his jaws and, grabbing all the food he can, swallows it whole and gapes for more (Ep. 72.8) ${ }^{44}$

An individual's actions with respect to food will, if he allows it, degrade him to the same level as or lower than an animal (animalium loco numeremus, Ep. 60.4). While an animal learns through satiety what should be the measure of its food and drink (Ep. 59.13), the glutton will willingly deny his human responsibility and ethical integrity (excedat ex hoc animalium numero pulcherrimo ac dis secundo; mutis adgregetur animal pabulo laetum, 'Nay, let him withdraw from the ranks of this, the noblest class of living beings, second only to the gods; let him herd with the dumb brutes - an animal whose delight is in fodder!', Ep. 92.7). ${ }^{45}$ And, just as birds fattened for the banquet (Ep. 122.4) resemble indolent people who live useless, indulgent lives (De Ben. 4.13.1), sluggish, slime-fattened oysters transform anthropomorphically into the greedy person who eats them (quid? illa ostrea, inertissimam carnem caeno saginatam, nihil existimas limosae gravitatis inferre?, 'What? Do you suppose that those oysters, a sluggish food fattened on slime, do not weigh one down with mud-begotten heaviness?', Ep. 95.25). Even a kitchen can develop the affected qualities of

43 Using the concepts of Epicurus and Stilpo as foils, Seneca discusses the issue of philosophical self-sufficiency in $E p .9$ of the $E M$, where it is summarized by the phrase se ipso esse contentum, cf. Hecato's phrase amicus esse mihi coepi, quoted by Seneca in Ep. 6.7; illum cui bonum omne in animo est, Ep. 45.9; [sapiens]qui omnia in se reposuit, Ad Helv. 13.4. For those who centre their existence in externals, and whose hopes, purpose, and existence depend on Fortune and not themselves, there is no certainty or guarantee of happiness. See Epp. 20.8; 55.4; 62.1-3; 72.7; 92.2; 109.8; De Vita Beata, 26.4; Ad Helv. 5.1; De Ben 7.2.4-5.

44 Pointedly, the meat and bread described in Ep. 72.8, in a quotation of Attalus, are a metaphor for the gifts of Fortune.

45 Cf. Ep. 121.24: sed in nullo deprendes vilitatem sui, <ne> neglegentiam quidem; tacitis quoque et brutis, quamquam in cetera torpeant, ad vivendum sollertia est ('In no animal can you observe any low esteem, or even any carelessness, of self. Dumb beasts, sluggish in other respects, are clever at living.') In Ep. 124.21-4, Seneca stresses how humankind's place is with god rather than non-rational animals. See also Cicero, De Officiis, 1.105-6; Aulus Gellius, Noctes Atticae, 19.2. 
the human eater it serves (ambitiosam popinam, Ad Helv. 10.3). Hunger, on the other hand, is not ambitiosa (ambitiosa non est fames, Ep. 119.14). In the midst of plenty, the rich can eat plainly, but the decision to do so (Ep. 87.1) is a moral and knowing response (disce parvo esse contentus, 'learn to be content with little', Ep. 110.18). ${ }^{46}$ Greed is a self-neglect that fails to comprehend its own best resource or action ${ }^{47}$ and, by ignoring the limits of self-control, a person can never achieve happiness (illa est voluptas et homine et viro digna non implere corpus nec saginare, 'True pleasure, worthy either of man or hero, comes not from filling and gorging the body', De Ben. 7.2.3).

From Seneca's philosophical viewpoint, over-eating is a culpable passivity and failure of Self (usum sibi, Ep. 114.25), which leaves one neither able nor willing to help oneself. Translating this into concrete terms, Seneca stresses how the luxuries of the banqueting table will soon be nothing more than the foul evacuation of an over-loaded stomach (eadem foeditas occupabit, Ep. 110.13). This is, at its basest level, the real value of all food (vis ciborum voluptatem contemnere? exitum specta, 'Would you despise the pleasures of eating? Then consider its result!', Ep. 110.13). ${ }^{48}$ Eating is a moral action of the Self, and self-awareness, judgment, control, and wise decision must determine and justify it, if it is to be an act that will ensure a purposeful experience and become a way of life (sani erimus et modica concupiscemus si unusquisque se numeret, metiatur simul corpus, 'We should be sensible, and our wants more reasonable, if each of us were to take stock of himself, and to measure his bodily needs', Ep. 114.27).

Eating has consequences that penetrate the fabric of individual philosophical existence and self-empowerment. Thus, instead of lecture halls, footsteps veer off towards cafés and eating houses (cocos numera...in rhetorum ac philosophorum scholis solitudo est: at quam celebres culinae sunt, quanta circa nepotum focos <se > iuventus premit!, Ep. 95.23)..$^{49}$ Here a person's best friends are likely to be cooks or those 20.10).

46 Cf. magnus ille qui in divitîs pauper est ('he is truly great who is poor amidst riches', Ep.

47 Humanity's delusion is to think that such behaviour is also, according to the fashion of the moment, their public duty (Ep. 95.28)

48 See Ep. 95.25. Marcus Aurelius uses similar psychology: 'When you are seated before...choice foods... impress upon your imagination that this is the dead body of a fish...a bird or a pig...penetrating them so as to see the kind of things they really are', in A. S. L. Farquharson and R. B. Rutherford (trans.), The Meditations of Marcus Aurelius Antoninus and a Selection from the Letters of Marcus and Fronto (Oxford, 1944, repr. 1998), 6.13.

49 'Count the cooks!... The halls of the professor and the philosopher are deserted; but what a crowd there is in the cafés! How many young fellows besiege the kitchens of their gluttonous friends!' Both Pliny, Natural History, 9.67 and Livy, 39.6 lament the esteem which cooks receive. 
who apply their minds to pleasure (cocos et ceteros voluptatibus nostris ingenia accommodantes sua, Ep. 88.18). From Seneca's perspective, cooks are superfluous (supervacuum sciet sibi cocum esse, Ep. 90.15), and yet these so-called 'professors of the kitchen' defile the age with their teaching (scientiam popinae professus disciplina sua saeculum infecit, Ad Helv. 10.8). ${ }^{50}$ Their doctrine is luxuria, a vice that signifies for Seneca an uncompromising corruption of moral being (Ep. 90.19) and of all that is good, right, safe, virtuous, and rational. ${ }^{51}$ Convincing a person to give up on himself, luxuria effectively leaves him with no valid choices (luxuria invictum malum et ex molli fluidoque durum atque patiens, 'Luxury is an incurable malady and from being soft and weak it hardens to endure anything', Nat. Quaest. 4B.13.11) ${ }^{52}$ Every mouthful with which a person 'loads his belly' (uentrem onerare, Ad Helv. 10.2 $)^{53}$ puts him at the mercy of a stubborn peevishness that has no need to eat (Epp. $17.4 ; 89.22 ; 110.12 ; 119.4)$ and in pursuit of a goal that is always shifting and can never be satisfied (quidquid illi congesseris, non finis erit cupiditatis sed gradus, 'However much you gather for it will serve not to end, but to advance desire', Ad Helv. 11.4). The person who eats too much is trapped in daily servitude to their stomach (cotidiana stomachi servitute, Nat. Quaest. 4B.13.11), ${ }^{54}$ and held in bondage to vice, passion, fear, desire, hope, fortune, and any other external and morally compromising situation. This is not the slavery of physical capture but the loss of libertas, the inner Stoic freedom (Ep. 65.16-17) of constantia, moral certainty, tranquillitas, and virtus. Although a banquet or the meat dole can be divided and carried away, peace and liberty are the kind of goods that are indivisible and 'belong in their entirety to all men just as much as they belong to each individual' (epulum et visceratio...discedit in partes: at

50 See also Epp. 51.4; 90.19; 123.1; De Prov. 5.4; De Ben. 1.10.2. In the Gorgias, Plato distinguishes between the doctor who benefits the body and the cook who advises on pleasure. Wilkins and Hill (n. 1) reiterate the ambiguous character of the cook: 'In the ancient world, they might be camp followers or slaves, or skilled artisans for hire' (28) and note that cooks became stock figures in Greek comedy (46).

51 hoc est luxuriae propositum, gaudere perversis nec tantum discedere a recto sed quam longissime abire, deinde etiam e contrario stare ('It is the motto of luxury to enjoy what is unusual, and not only to depart from that which is right, but to leave it as far behind as possible, and finally even take a stand in opposition', Ep. 122.5).

52 References to luxuria often occur in descriptions of food, e.g. Epp. 77.16; 78.23, 25; 95.18, 19, 33, 41; 110.12; Ad Helv. 10.1; De Vita Beata, 11.4; Nat. Quaest. 4B.13.6.

53 Also Ep. 47.2: Onerat distentum ventrem ('he loads his belly until it is stretched'). See also epp. 89.22; 110.12-13; 114.25-6. Cf. Ep. 17.4; Nat. Quaest. 4B.13.5.

54 Seneca likes this image of the stomach enslaved, and also uses it in Ep. 60.4: ut ait Sallustius, 'ventri oboedientes' ('those who, as Sallust puts it, "hearken to their Bellies"') and Ep. 124.3: inprobamus gulae... addictos ('we condemn men who are slaves to their appetites'). 
haec individua bona, pax et libertas, ea tam omnium tota quam singulorum sunt, Ep. 73.8). ${ }^{55}$ Unlike eating (Ep. 73.8), philosophy will enslave a man to liberation (hoc enim ipsum philosophiae servire libertas est, $E p$. 8.7). The person who has lost his libertas has lost his freedom to achieve and maintain a happy life.

Lacking the freedom of rational self-actualization to depend upon oneself, resist luxuria, and make right and virtuous choices, Seneca's diners - the gluttonous banqueter, the fastidious eater, and the sated diner (all variations of the same breed) - bring to mind the spectators at the gladiatorial games (Ep. 7.3-5) who become caught up and carried away by the crowd psychology of the event. ${ }^{56}$ Like the games, the dinners Seneca describes were usually public affairs and, just as everyone joins in and cheers on the cruel events at the gladiatorial games, a meal also becomes a spectacle and a performance in which everyone participates. ${ }^{57}$ Fish are no longer left to die in the sea or under the fisherman's surveillance, ${ }^{58}$ and the chance to view the death of a surmullet is an eagerly attended event even when one should be following the funeral of a family member or sitting by a dying friend (Nat. Quaest. 3.18.6-7). ${ }^{59}$ Likewise, Apicius gains the attention of his community with his spectacular banquets and is able through them to incite the dissipation of his fellows (ciuitatem in luxuriam suam conuerteret, $A d$ Helv. 10.10). Seneca is always ready to emphasize the moral dangers of human association or submission to public attitude and opinion, and he also knows that nothing brings people together in

\footnotetext{
55 Inwood (n. 19), 317 writes: 'The kind of philosophy which brings us freedom is a solid knowledge of the real values of things which affect our concrete human lives and which if misunderstood, misevaluated, or muddled will enslave us to our passions.' See Epp.17.6; 51.9; 80.4-5; 85.28; 110.20 .

56 Just as cookshops are preferred over philosophical Schools, Seneca notes in Ep. 80.1 how people also prefer to go to the gladiatorial games. In Ep. 18.1, Seneca remarks how preparations for the Saturnalia seem to have become the business of an ordinary day and questions how best to participate in them, by neither giving in to the public mood nor conspicuously excluding oneself either (cf. Ep. 5.1-4).

57 For Seneca's humanitarian stance against the gladiatorial games, his principal argument in ep. 7, see C. Richardson-Hay, 'Mera Homicidia: A Philosopher Draws Blood - Seneca and the Gladiatorial Games', Prudentia 36 (2004), 87-146.

58 'quo coctum piscem? quo exanimem? in ipso ferculo expiret...huc afferatur; coram me animam agat.' "“Why a fish that is cooked or dead? Let it die on the dinner plate... Bring it here. Let it die in front of me"', Nat. Quaest.3.18.2-3). Garnsey (n. 1), 116-8 and Dunbabin (n. 1), 238, n. 22, distinguish fish as a 'gastronomic luxury' (Dunbabin). In Satire 5, Juvenal rails against the importation of fish from Corsica. The eating of fish is singled out as 'a mark of greed' in Book 1 of the Deipnosophistae (1.25d). See Wilkins and Hill (n. 1), 259.

59 See also Epp. 78.23-4; 110.13. Gowers (n. 1), 38, n. 171, cites Ammianus Marcellinus' account (28.34) of anxious Romans screaming and rushing into the kitchen to crowd over slabs of meat in preparation. See Dunbabin (n. 1), 64.
} 
an atmosphere of spiritual lassitude and complicity better than eating. ${ }^{60}$

At the same time that these gastronomic events reveal the fantastic dishes and loaded tables of the banquet, they also expose to view the gorging participants - people without the will, the courage, or the moral insight not to become part of the show (cf. Epp. 5.1-6; 18.2-4). It is not the food but the diner who becomes the real spectacle, as he exhibits his diverse appetite, the quantity of his consumption, and its insatiablity. Eating is a form of self-exhibition that draws its participants against any better judgment into its performance (Ad Helv. 10.11) and Seneca directly enjoins the reader 'to see' for himself (vide) the gluttonous arena where greed claims supremacy (vide quantum rerum per unam gulam transiturarum, 'Mark the number of things - all to pass down a single throat', Ep. 95.19). ${ }^{61}$ Unlike the gladiatorial stage, however, there is no opponent and the individual's battle at the dinner table is with himself. To eat until nothing more can be kept down (Epp. 47.2; 95.21; Ad Helv. 10.3), ${ }^{62}$ to drink until one drowns in the very dregs (Epp. $83.16 \mathrm{ff} . ; 119.14)$, to recline at tables so lavish that they seem to eat themselves (Ep. 95.27) or so ostentatious (Ep. 110.12; De Tranq. An. 1.6; De Brev.Vit. 12.5) that they are seemingly accompanied by the kitchen (cenam culina prosequitur, Ep. 78.23) are cowardly and deluded acts of self-desertion (cf. Epp. 18.3; 124.21-4). One becomes one's own quarry and defeats oneself in a contest where there can be no victor. And, in this public context where diners view the spectacle of themselves in other diners, the reader, who almost certainly likes to eat too, is left uncomfortably to infer their own participation in the display before them. Aware of his own act of viewing, the reader cannot ignore himself as the moral dilemma shifts and becomes his

60 Moral degradation can, like a disease, spread insidiously from one person to another: serpunt enim uitia et in proximum quemque transiliunt et contactu nocent ('For vices spread unnoticed, and quickly pass to those nearest and do harm by their contact', De Tranq. An. 7.3). In Ep. 7.6 Seneca exaggerates his point, citing the moral hazards even to Socrates, Cato, and Laelius. See Epp. 7.2-3; 59.9; 81.29; 123.8-11; De Brev.Vit. 2.3; De Ira, 3.8.1.

61 The concept of spectacle pervades Seneca's works, especially his tragedies. Shelton (n. 20), 101 considers that Seneca's 'interest in the spectacle is not to be found...in their social implications, but in the opportunities they provide for reflection upon one's own personal philosophic progress'. Cf. Tarrant's remark that 'Seneca's moral imagination was...stimulated by wickedness performed with flair and vigor', (n. 20), 11. See further, C. A. Littlewood, Self-Representation and Illusion in Senecan Tragedy (Oxford, 2004), 172-258.

62 Seneca also refers to the fashion that developed of serving together different courses or dishes that were once kept separate, thereby blending the food as if it were already in the diners' stomachs (Epp.95.27; 114.9). See further Dunbabin (n. 1), 160-61 and Wilkins and Hill (n. 1), 77-8 ('Order of the Meal'). 
own challenge. ${ }^{63}$ The reader cannot sidestepped this issue because he needs to prove his own resolution.

If there is, as E. Gowers proposes with reference to De Vita Beata, $7.3,{ }^{64}$ a 'moral topography' of Rome which 'allow[s]... simple and luxurious eating to co-exist', this was not for Seneca an actual 'map' of the city. Seneca's passage, which pits virtue (found in the temples, the Forum, or the senate house) against pleasure (the haunt of brothels, cookshops, or bathhouses), ${ }^{65}$ is part of a discussion that contrasts Epicurean and Stoic accounts of the role of sensual pleasure in the good life (De Vita Beata, 7.2) and is not even concerned with particular physical locations. Seneca is instead writing about a person's ethical capability and philosophical percipience, his discernment about the places that he visits ${ }^{66}$ and the people with whom he associates there (Ep. 7.1-6). It does not matter whether the good man visits either the temple or the cookhouse because, no matter what kind of pleasure or culinary temptation he encounters at the latter, his behaviour will be the same regardless (numquam enim recta mens uertitur, 'for the right-thinking mind never alters', De Vita Beata, 7.4). Conversely, a bad man can visit a temple but this is no guarantee that he will not stop off at the cookshop and indulge himself on the way home. It is moral commitment and judicious action that will motivate a person's character (Ep. 23.7), no matter where they are, who they are with or whatever activity is involved (Ep. 31.6). As Seneca explains, bona ista aut mala non efficit materia sed virtus ('It is not the material that makes these actions good or bad; it is the virtue', Ep. 71.21). In this instance, Seneca is asking whether reclining at a banquet or submitting to torture are equally good actions. He lauds the individual who endures the pain of torture bravely and nobly as someone of virtue and honour. In comparison, the typically shameful and gross behaviour at a banquet is an evil (Ep. 71.21). Significantly, the ideas of banqueting and torture come together more than once in Seneca's mind (see, for example, Epp. $47.4 ; 51.4 ; 66.16) .{ }^{67}$

${ }^{63}$ It is a commonplace that, as the letters of the $E M$ progress, their recipient, Lucilius, gradually fades so that the letters seem more and more to be addressed to a general audience, the ordinary Roman.

${ }^{64}$ Gowers (n. 1), 18.

65 uoluptas humile seruile, inbecillum caducum, cuius statio ac domicilium fornices et popinae sunt ('Pleasure is something lowly, servile, weak, and perishable, whose haunt and abode are the brothel and the tavern', De Vita Beata, 7.3).

${ }^{66}$ The Senate (public office) is not necessarily a place of virtue (Epp. 68.10; 84.11; 95.3; 118.2-4).

${ }^{67}$ Cf. supplicia luxuriae ('the tortures of high living', Ep. 95.18); infelicis luxuriae ista tormenta sunt ('Those things are but the instruments of a luxury which is not "happiness"', Ep. 119.14). 
When Seneca describes in vigorous and exacting, often sickening, detail the full tables of the Roman convivium and the shameless, devouring surfeit of human consumption, these details are not incidental, convenient padding, or a sop to tradition but an integral part of Seneca's philosophical vocabulary. Indeed, on the level of common, everyday experience, food is so basic to the functioning and habits of human affairs ${ }^{68}$ that its discussion (whether one is speaking to the gluttonous, the ascetic, or the starving) will always have some impact. ${ }^{69}$ Certainly, to define the law of natura very early on in the Epistulae Morales as an instruction about the necessities of eating, drinking, and shelter, makes this notion, which accounts for the strength, justice, and virtue of human philosophical and moral existence, ${ }^{70}$ accessible in the most basic way (lex autem illa naturae scis quos nobis terminos statuat? non esurire, non sitire, non algere, 'Do you know what limits that law of nature ordains for us? Merely to avert hunger, thirst and cold', Ep. 4.10). Natura (which is often personified) demands nothing except enough (nihil praeter cibum natura desiderat, Ep. 119.13), so that even too little is sufficient for her needs (naturae satis est etiam parum, Ad Helv. 10.11). In essence, 'the starving man despises nothing' (nihil contemnit esuriens, Ep. 119.4) ${ }^{71}$ and he is always more replete with even the scantiest morsel than the person who eats until he explodes (De Prov. 4.10) because his 'fulfilment' is a moral knowledge that knows and accepts what is enough. ${ }^{72}$ Unlike greed, which herds one with the animals (Ep. 92.7), this knowledge confirms human equality with the gods (disce parvo esse contentus...habemus

In De Prov. 3.9-10, Maecenas' self-indulgence is opposed to the virtue of Regulus' torture. For the Romans, the ability to endure pain was, of course, a test of virtus (Seneca, Epp. 24.14; 78; Cicero, Tusculan Disputations, 2).

68 'For nothing in the world is so incontinent as a man's accursed appetite. However afflicted he may be and sick at heart, it calls for attention so loudly that he is bound to obey it' (Homer, Odyssey, 7.216-18). Augustine notes how Varro's catalogue of gods deals first with those who represent man and then with the gods of necessities such as food and clothing (City of God, 6.9).

${ }^{69}$ Garnsey (n. 1), 80 writes: 'Food is often at the centre...because the food we eat and the way we eat it are an integral part of social behaviour and cultural patterns'. See further, 6-7.

70 As Seneca states throughout all his works, propositum nostrum est secundum naturam vivere ('Our motto, as you know, is "Live according to Nature"', Ep. 5.4). Also cum rerum natura delibera (Ep. 3.6); sequere naturam (Ep. 90.16). See Epp. 118.12; 119.2-3; 122.19; 124.7. Cf. $A$ natura luxuria descivit (Ep. 90.19). See Inwood's discussion (n. 19), 'Natural Law in Seneca', $224-48$

71 fames me appellat...ipsa mihi commendabit quodcumque conprendero ('Hunger calls me...my very hunger has made attractive in my eyes whatever I can grasp', Ep. 119.4). See also Ep. 123.2-3; cf. Epicurus, Letter to Menoeceus, 130-1.

72 magna pars libertatis est bene moratus venter et contumeliae patiens ('A great step towards independence is a good-humoured stomach, one that is willing to endure rough treatment', Ep. 123.3). 
aquam, habemus polentam; Iovi ipsi controversiam de felicitate faciamus, 'Learn to be content with little...we have water, we have porridge; let us compete in happiness with Jupiter himself', Ep. 110.18). To take more or too much is a corrupt decision ${ }^{73}$ and an abandonment of Nature's appointed order. ${ }^{74}$ Only if a person is willing to try can regular practice or endurance change and shape habits and frame of mind (Epp. 16.1; 18.3; 87.1; 123.3).

Seneca's works are full of similar assertions, whether qualified by Nature's dictates or general exhortations of modus against immoderation (non servamus modum rerum, 'we observe no moderation', Ep. 13.13). Senecan concepts of behaviour, even social interaction (Ep. 5.1-6), were based on the idea of modus, or a mean between two extremes (hic mihi modus placet, Ep. 5.5) ${ }^{75}$ Seneca's terminology varies, occurring synonymously in the idiom of sufficiency (sat, satis, sufficio), necessity (primus habere necesse est, proximus quod sat est, Ep. 2.6), moderation (modus, modicum), or, antithetically, in terms of prohibition of the supervacuus (ad supervacua sudatur, 'It is the superfluous things for which men sweat', Ep. 4.11). Virtue alone possesses moderation (Ep. 85.10; De Ben. 2.16.2), and in the physical world the lesson is the same, whether Seneca is talking about food, money, clothing, or shelter (necessaria tibi ubique occurrent...tunc te admirare cum contempseris necessaria, "What is necessary will meet you everywhere...The time to admire your own conduct is when you have come to despise the necessities', Ep. 110.11-12). The tasty morsels for which people reach will never satisfy the stomach of someone who can not accept that 'enough' is 'sufficient', who does not know that what is 'sufficient' is only what is 'necessary', or that what is 'necessary' does not have to be a full measure and can be modicus.

The ravages made on earth and sea to satisfy appetite are a shameful and offensive picture of cloying fastidium and wearied indulgence (Ep. 89.22; De Vita Beata, 11.4; Ad Helv. 10.2-3) that have nothing to do with natural needs, or any actual need at all (epulas quas toto orbe conquirunt nec concoquere dignantur, 'they do not deign even to digest the feasts for which they ransack the whole world', Ad Helv.

73 Corporis exigua desideria sunt...quidquid extra concupiscitur, uitiis, non usibus laboratur' ('The wants of the body are trifling... if we covet anything beyond, we toil to serve, not our needs, but our vices', Ad Helv. 10.2). See Epp. 8.5; 110.10. Cf. Cicero, De Finibus, 2.8.25; Horace, Satires, $1.2 .114 \mathrm{ff}$.

74 In Ep. 122, where revellers banquet at night and sleep during the day, where people drink while fasting and eat when intoxicated, Seneca asserts, with reference to Stoic natura (Ep. 122.17), that there is a proper order to things.

75 See Epp. 18.4; 23.6; 92.11. 
10.3). Seneca exclaims in frustration, quam facile est extinguere sitim sanam! ('How easy it is to quench a healthy thirst!', Nat. Quaest. 4B.13.10). ${ }^{76}$ But people who are only mindful of quantity or are blindly seeking innovation (ventrem...delectari, Ep. 119.3) and diversity in taste and selection of food (Ep. 110.12; Ad Helv. 10.6-7), even in the presentation of courses ( $E$. . 114.9), are people who are 'unable to look to the end and cast away superfluous things' (finem omnium rerum specta, et supervacua dimittes, Ep. 119.4).$^{77}$ For his part, Seneca is constantly perplexed by the motivation of unhealthy minds that remain hostage to their bellies (si ad sanam illis mentem placeat reuerti, quid opus est tot artibus uentri servientibus?, 'if men should be willing to return to sanity of the mind, what is the need of so many arts that minister to the belly?', Ad Helv. 10.5).

People who eat too much and too often live misguided and philosophically inept lives so that death, the fear of its approach, and how to deal with it (an ever-present topic in Seneca's writings), are inevitably complicated by a person's compulsive enslavement to his appetite. The revellers at the unnatural night banquets of Ep. 122 are already, in moral terms, dead (Ep.122. 10), even as the banquet is a cynical image of a funeral feast or a metaphor for death itself. ${ }^{78}$ In the case of suicide, a Stoic doctrine (cf. Ep. 12.10), the acceptance of death can be troublesome because a decision must be made to give up and leave behind the pleasures indulged in during life. Seneca's correspondent in Ep. 77, for example, will literally have to be torn (divelleris) from them (atqui haec sunt a quibus invitus divelleris, Ep. 77.16). He has become, in his culinary debauchery, merely a wine-strainer (saccus es, Ep. 77.16). ${ }^{79}$ Nothing (friends, love of country, or worldly ambition) can measure up to his desire for continued gastronomic experience, and Seneca is unremitting as he taunts his friend with his need to remain in the empty fish market where he has already eaten everything anyway (confitere...invitus relinquis macellum, in quo nihil reliquisti, Ep. 77.17). Tainted by the

76 The alliterating and emphatic sanam is of course a word of special philosophical significance: cf. aeger animus. See also Epp. 4.10; 60.3; 119.15; Ad Helv. 10.11, 11.1-4; De Vita Beata, 20.5.

77 Cf. consilium rerum omnium sapiens, non exitum spectat ('the wise man regards the reason for all his actions but not the results', Ep. 14.16).

${ }^{78}$ See further, Edwards (n. 25) 161-78, who goes on to discuss Ep. 12 of the EM. Also Motto (n. 16), 177-8. Details about food punctuate the remainder of the letter (Ep. 122.5-6, 9, $12-13,16,18)$. Life is directly compared to a banquet in Ep. 77.8 .

${ }^{79}$ Gummere (n. 9), ii.178 cites Pliny, 14.22 (quin immo ut plus capiamus, sacco frangimus vires), commenting that 'Strained wine could be drunk in greater quantities without intoxication'. 
odour of fish that have not yet been given time to rot, this man's life is a self-mockery.

The greedy gastronome is neither able nor wants to give up eating, and is unable to face the prospect of death because of it. ${ }^{80}$ And yet, as Seneca goads, death could overcome him during his next meal of mushrooms ${ }^{81}$ (mortem times: at quomodo illam media boletatione contemnis! Ep.77.18; 'You are afraid of death; but how can you scorn it in the midst of a mushroom supper?'). ${ }^{82}$ The glutton is controlled by greed because he does not know how to control his fear of death and live a meaningful life (vivere vis; scis enim?, 'You wish to live; well, do you know how to live?', Ep. 77.18). This question echoes through all Seneca's discussions on death because, for everyone else like this man, who is eating his way through life and has given in without consequence to pleasure or desire, their existence is already a kind of death (mori times: quid porro? ista vita non mors est?, Ep. 77.18). Measure in one's eating, on the other hand, demonstrates judgement and the moral perception that means not just knowing how to live a more complete life but also knowing how to die and face death with equanimity. ${ }^{83}$ It is but a short, almost logical, step at the end of the letter for Seneca to thrust home his point about suicide (quomodo fabula, sic vita: non quam diu, sed quam bene acta sit, refert, 'It is with life as it is with a play, - it matters not how long the action is spun out, but how good the acting is', Ep. 77.20). ${ }^{84}$ The image is one of the

80 The coward who fears death is like the man 'immoderately given to wine who drains the jar dry and sucks up even the dregs' (prope est a timente qui fatum segnis expectat, sicut ille ultra modum deditus vino est qui amphoram exsiccat et faecem quoque exsorbet, Ep. 58.32). Cf. Ep. 98.15.

81 A mocking allusion to the death of Claudius, who died as a result of poisoned mushrooms. See Ep. 95.25. Seneca did not himself eat mushrooms (Ep. 108.15).

82 The Elder Seneca notes a similar paradox in the Controversiae: qui in carcere vixerunt in convivio perierunt ('Those who survived in a cell died at a dinner', 9.2.1; text and translation from M. Winterbottom's two-volume edition in the Loeb Classical Library [1974]).

83 nihil tamen aeque tibi profuerit ad temperantiam omnium rerum quam frequens cogitatio brevis aevi et huius incerti: quidquid facies, respice ad mortem ('But nothing will give you so much help toward moderation as the frequent thought that life is short and uncertain here below; whatever you are doing have regard for death', $E p$. 114.27). In $E p$. 78, which has already considered the pleasures of body and mind in terms of food ( $E p .78 .22 \mathrm{ff}$.), Seneca's language continues to have food overtones when he moves on to discuss man's fear of death, e.g. vitam enim occupare satietas sui non potest...numquam in fastidium veritas veniet: falsa satiabunt...perceptus longissimae fructus est (Ep. 78.26-7). Seneca also introduces his argument in the person of a greedy man fastidious about his food ( $E p$. 78.25).

84 Seneca also manipulates the idea of Roman suicide in Ad Helv. 10.10, where he describes how Apicius apparently killed himself when his fortune was reduced to ten million sesterces. He, the epitome of luxurious living, considered his life had become one of starvation and deprivation. See also Martial, 3.22. 
stage, and its terms (bene acta) exclude the man who must eat no matter what. ${ }^{85}$

Stoic conceptions of 'good acting' (of living a full and just life, Epp. 90.1; 93.2) were founded on resolution, purpose, knowledge, perseverance, and consistency (ostendit illam nobis ordo eius et decor et constantia et omnium inter se actionum concordia, 'Virtue has been manifested to us by this man's order, propriety, steadfastness, absolute harmony of action', Ep. 120.11). The actions of an indiscriminate, greedy individual would also therefore have been negative indicators for Seneca of inconstancy, instability, or the manifestation of a disordered spirit (aegri animi ista iactatio est, Ep. 2.1). While the common person veers from idea to idea (Ep. 20.4) or place to place (Ep. 2.1), unable to make valid judgments or justify any certainty (Ep. 23.7-8) and never assured of their goal (Ep. 52.1), the Stoic sapiens (fixum atque fundatum, Ep. 35.4) is characterized by an unwavering stability of thought and action (idem erat semper et in omni actu par sibi, 'He has always been the same, consistent in all his actions', Ep. 120.10). ${ }^{86}$ In contrast to the many dining halls, kitchens, even countries that occupy a person's desire for delicate and exotic foods (even if only in thought) and the need to eat as many things as possible in as much quantity as possible, the sapiens (without caring what he eats) follows a single, inevitable iter (Ep. 8.3), the metaphorical via to which all adherents of the philosophical life commit themselves (una ad hanc fert via, et quidem recta, 'There is but one path leading thither, and it is a straight path', Ep. 37.4). Along this 'road', and despite any setbacks, the person in pursuit of philosophy will strive to achieve the summum bonum of moral virtus (De Vita Beata, 7.4), becoming 'strong and healthy' (Epp. 78.22-3; 80.4; 95.28-9), not just in mind but also in body (Ep. 15.1). For the person whose 'philosophy' is food, the summum bonum is a more pragmatic matter of flavours, colours, or sound (homines, cuius summum bonum saporibus et coloribus et sonis constat, Ep. 92.7), as the moral self is debased into the physical,

85 Dunbabin (n. 1), 126 stresses the inconclusive associations between dining and death in Roman thought. Depictions of (communal) banquets on funerary monuments either use the banquet as a metaphor for life's enjoyment or as a representation of hopes for a happy afterlife. The introduction of death into the convivium of the living in convivial poetry (Horace, Martial, and the Satyricon, for example) also suggests seizing present worldly enjoyment. Despite the ambiguities, the sense is that this confrontation between death and dining was 'an attempt to come to terms with mortality' (Dunbabin, 140).

86 Sciant omnia praeter virtutem mutare nomen ('They must know that everything except virtue changes its name', Ep. 95.35). Vices, significantly, 'do not wait expectantly in one spot, but are always in movement' (Non expectant uno loco vitia, sed mobilia, De Ben. 1.10.3). See Epp. 20.5; 66.11; 92.3; 104.17; 120.20, De Vita Beata, 5.3. 
disturbed by the emotional, and distrusted by the irrational ( De Ben. 7.2.2-3). While food's pleasure will cloy in the belly, the wise person's happiness is, in contrast, 'constant, serene, always uncloyed' (hanc voluptatem aequalem, intrepidam, numquam sensuram sui taedium percipit, De Ben. 7.2.4).

Philosophy is its own kind of 'food', and Seneca is always alert to the ways in which details about food and its consumption can be manipulated to clarify and explicate the world of philosophy. In Ep. 47 , Seneca, whose attitude towards slavery was atypically humani$\operatorname{tarian},{ }^{87}$ extends this alertness and uses a description of a banquet to focus upon Roman maltreatment of slaves and the inhumane cruelty they were forced to endure. The Roman master who considers it degrading to sit at table with his slaves $(E p .47 .8)^{88}$ is himself an offensive figure of gastronomic gorging and a noxious spectacle of self-explosive satiation (est ille plus quam capit, et ingenti aviditate onerat distentum ventrum...ut maiore opera omnia egerat quam ingessit. at infelicibus servis movere labra ne in hoc quidem, ut loquantur, licet...nocte tota ieiuni mutique perstant, 'The master eats more than he can hold, and with monstrous greed loads his belly until it is stretched...so that he is at greater pains to discharge all the food than he was to stuff it down. All this time the poor slaves may not move their lips, even to speak...All night long they must stand about, hungry and dumb', Ep. 47.2-3). In contrast to the rigid lips of the slaves that are forced to remain shut, not just preventing eating but also other natural functions such as coughing, sneezing, or talking, the master's mouth overworks itself, opening too far and too often with a frequency that turns it into an unnatural point of discharge. This nauseating behaviour is replicated all around the banqueting table and serves to define the moral stature of men whose public status only accentuates their crude debasement (cum ad cenandum discubuimus, alius sputa deterget, alius reliquias temulentorum <toro $>$ subditus colligit. alius pretiosas aves scindit, 'When we recline at a banquet, one slave mops up the disgorged food, another crouches beneath the table and gathers up the leftovers of the tipsy guests. Another carves the priceless game birds', Ep. 47.5) ${ }^{89}$ As both master and guests eat lavishly and without

\footnotetext{
87 'servi sunt.' immo homines (“"They are slaves," people declare. Nay, rather they are men', Ep. 47.1). Cf. Epp. 7; 95.33.

88 Cato the Elder apparently often ate with his slaves when at home: see Wilkins and Hill (n. 1), 61, 72, 202 .

89 As the list of duties incumbent on the slaves grows (Ep. 47.6-8), Seneca also hints at sexual obligations. See Cicero, De Finibus, 2.23; Philippics, 2.23.
} 
need when those who serve them are hungry or underfed, ${ }^{90}$ their behaviour is heartless but it also demonstrates their own moral vacuum and self-dissipation. Paradoxically, their greatest cruelty is to themselves and, in this environment of social and mutual self-encouragement, to their peers and fellows as well (cf. Ep. 47.11-12). The diners, slaves to themselves (Ep. 39.5-6), are the real slaves and, as Seneca later states, there is no slavery worse than that which is voluntary (nulla servitus turpior est quam voluntaria, Ep. 47.17). The ever-attendant slaves, who are metaphorically trapped between the jaws and inside the appetites of all the diners present, are bystanders at a show put on by luxuria and her cohorts and, despite the degraded and hostile treatment they receive, they are all the better for not being a part of it. There is a moral lesson for them too in such behaviour, should they ever escape their present situation and rise above it (Ep. $47.9 \mathrm{ff}$.). The humanitarian aspect of Seneca's argument mingles with the philosophical issues involved in overeating (cf. Ep. 27.6-7) and the result is a double-edged view of social, human, and individual moral turpitude. Seneca was both a philosopher and a humanitarian and, from his perspective, the master's actions rebound against him either way. It is not as a master of other men that he has failed, but as master of himself.

\section{Conclusion}

Although ancient writers of serious genre literature had an ambivalent stance towards the inclusion of food in their writings, Seneca is never hesitant about culinary exposition. Like satirical writers who fitted it to their own effect, it is for him, as a philosopher, a tool with its own profound reference points and connotations, which he uses pointedly for his own Stoic purposes. ${ }^{91}$ The often repellent vividness of his illustrations only makes his explication more meaningful, even as, from the opposite viewpoint, the more tempting food is, the more urgently (from a perspective of moral growth and rational integrity) it needs to be resisted. Food is a fundamental aspect of Seneca's moral language ${ }^{92}$ and its interpretation emerges in terms of ideas, principles, values, and modes of living.

90 The heavy, physical work of slaves could require a very substantial diet: see Wilkins and Hill (n. 1), 61.

${ }_{91}$ Note Garnsey's distinction (n. 1), 10, between food as 'nutrition' and food as 'protocol'.

92 The word sapiens, a crucial word in Seneca's discourse signifying the Stoic wise man, was often used in satire in its original sense of 'juicy, flavoursome, or tasty' and was a 'favourite' pun 
Although Seneca, in his later years anyway, advocated a simple diet for himself (Epp. 83.6; 87.3; 108.15) ${ }^{93}$ his writings are full of gastronomic descriptions. ${ }^{94}$ But, if Seneca was living in a culture interested in - even obsessed with - culinary experience, and if the imagery and description of food had its own tradition (literary or philosophical), it should not be surprising that Seneca would employ a subject able to be used so readily and with so much purpose as pedagogical commentary and ethical instruction. Food is a physical requirement of life but its tantalizing nature and frequent misuse make it an easy and relevant means of enforcing ideas. The distended, seemingly unfillable paunch, the disgusting ejaculations from mouths that never shut are images that encapsulate ideas about moral negligence with a gross vividness that also denies the aspirations of the animus (Ep. 92.33) with energetic and shocking contrast. The distinction between right and wrong, good and bad, philosophical freedom and slavery, reason and folly is conceptualized in terms of the body, and its debate (which is visual and sensual) makes a vigorous and powerful impression. Philosophy is 'corporealized', the materialism of the body grounding conceptions, ideas, and arguments into a tangibility and substance that underscores the actuality and authenticity of philosophical truth and moral expectation.

This contrast of animus and corpus (stomach, mouth, throat) informs and substantiates all of Seneca's culinary discussions where antithesis is a fundamental means of exposition. While 'health' is opposed to 'illness', natura to luxuria (Ep. 95.15), reason to emotion, self-knowledge or self-control to self-violation and self-gratification, modus to immoderation, sufficiency to insufficiency, necessity to fastidium, constancy to diversity, and happiness to self-delusion, these contrasts are further imaged in the metaphorical opposition of 'digestion' (spiritual and intellectual) and unassimilated bodily evacuation. The larger contrast between the simplicity of an earlier age and the

(Gowers [n. 1], 8, 39). Ius (the 'law', 'what is right or just') was also used to signify 'sauce' or 'gravy'. Seneca, whose allegiance is philosophical, never appears (unlike Horace - see Gowers [n.1], 137) to make these verbal plays. See Edwards (n. 25), 173 for his play on the derivation of convivium from 'living together' in Ep. 122.

93 In Ep. 108.22, Seneca describes his youthful venture into vegetarianism. However, for the sake of his father, who feared for his safety in the difficult philosophical circumstances of the time, he soon gave it up.

${ }_{94}$ Seneca obviously participated in public and imperial banquets, where an excessive lifestyle was the norm, up to the very last years of his life. It was also during these years, however, that he withdrew from Nero's court (Tacitus, Annals, 15.37; Suetonius, Nero, 31). Claims of hypocrisy have been levelled at Seneca since his own lifetime. He was, for instance, one of the wealthiest men in Rome and yet he advocated poverty. The debate is an old one and is not the issue here. 
extravagant turpitude of the present is another branch in this argument of human consequences. ${ }^{95}$ And, while antithesis creates perspective and requires judgement and choice, assent or dismissal, ${ }^{96}$ this ability to differentiate, to choose, and to decide is the basic tool of advancement along philosophy's recta via (bona et mala, honesta et turpia, iusta et iniusta, pia et impia, virtutes ususque virtutum, rerum commodarum possessio, existimatio ac dignitas, valetudo, vires, forma, sagacitas sensuum haec omnia aestimatorem desiderant, 'Things good and evil, honourable and disgraceful, just and unjust, dutiful and undutiful, the virtues and their practice, the possession of comforts, worth and respect, health, strength, beauty, keenness of the senses - all these qualities call for one who is able to appraise them', Ep. 95.58).

The question of whether to eat or not to eat is code for moral purpose, ethical perception, interpretation, rational capability, and personal fortitude. Gastronomic description and images of food are not the details of satire but information about the actions of an individual in the service of his Self, his integrity, happiness, and self-sufficiency. Food in Seneca's language is 'food for thought'. It symbolizes attitude, motivation, and knowledge, and the lessons it teaches are about the proper ordering and the proper conduct of life so that we know what really is 'nourishing', 'healthy', and 'life-sustaining'. Seneca is not trying to put anyone off his dinner, but what one puts in his mouth and how much is a philosophical choice. We are, it is said in popular idiom, what we eat, but for Seneca we are more importantly what we do not eat. Food is essential to the continuance of life, but the plentiful food described at Seneca's tables is not for eating. His world of eating is infiltrated by Stoic purpose and translates into an internal, spiritual world of ratio, stultitia, virtus, and vitium. Using modern jargon, Seneca might say 'Eat healthy!' But, if so, this is an ethical decision about moral improvement and transformation, self-realization, and philosophical truth.

95 In Ep. 95, Seneca recalls a nobler age in past times when wickedness had not spread so perniciously and basic common sense (cf. decreta) was all that was required for any moral correction (Ep. 95.13-14). The extravagance of current eating practices causes Seneca to launch into a long disquisition (cf. Ep. 90.5, 18-20) that deals with all his key ideas about the immorality of over-eating (e.g. modus [Ep. 95.22, 30], fastidium [Ep. 95.26, 28-9], the idea of Self [Ep. 95.18], imagery of the stomach [Ep. 95.24], cooks and cafés, [Ep. 95.23]). People used to be 'refreshed by food in which only a hungry man could take pleasure', even as they enjoyed 'plain and wholesome health' (excipiebat illos cibus qui nisi esurientibus placere non posset...simplex erat ex causa simplici valetudo, Ep. 95.18). See also Ep. 90.44-6; 114.11; De Ben. 1.10.1. See further Garnsey (n. 1), 78, 81; Wilkins and Hill (n. 1), 36-7, 198-9, 202 ff.

96 Gowers (n. 1), 12 refers to 'some essential polar distinctions, between simple and luxurious, raw and cooked, foreign and native food...[which] represent conceptual divisions, and give us a broad outline for considering Roman culture'. 